\title{
Influence of antifertility agents Dutasteride and Nifedipine on CatSper gene level in epididymis during sperm maturation in BALB/c mice
}

\author{
Archana Srivastav, Bendangla Changkija, Kunal Sharan, Geet Kumar Nagar and \\ Falgun W Bansode
}

Division of Endocrinology, Central Drug Research Institute, Lucknow, India

Correspondence should be addressed to A Srivastav; Email: archana1849@gmail.com

\begin{abstract}
Calcium $\left(\mathrm{Ca}^{2+}\right)$ signaling is critical for successful fertilization. In spermatozoa, capacitation, hyperactivation of motility and the acrosome reaction are all mediated by increases in intracellular $\mathrm{Ca}^{2+}$ through CatSper (sperm-specific cation channel). The CatSper channel complex contains four pore-forming $\alpha$ subunits (CatSper1-4) and five accessory subunits called $\beta, \delta, \varepsilon, \gamma$ and $\zeta$. Genetic deletion of any of the four CatSper genes in mice results in loss of hyperactivated motility and male infertility. Despite their vital role in male fertility, almost very little is known about influence of antifertility agents on CatSper gene expression in epididymis and epididymal spermatozoa. Therefore, we performed quantitative real-time qPCR analysis for CatSper expression in the epididymis and epididymal sperm of BALB/c mice after treatment with Dutasteride (DS), a dual 5- $\alpha$ reductase inhibitor and Nifedipine (NF) a calcium channel blocker as positive control. We observed that treatment with antifertility agents Dutasteride and Nifedipine induced significant decreases in the caput and cauda epididymal sperm counts, motility and fertility which could partly be attributed to alteration in the normal morphology of the sperm associated with downregulation/upregulation of CatSper mRNAs in epididymis and epididymal spermatozoa of male BALB/c mice. These can be explained on the basis of interference with mechanisms affecting calcium ion signaling resulting in changes in intracellular calcium required for sperm activity, finally affecting sperm maturation and fertility of male BALB/c mice. These studies provide some novel avenues for developing new male contraceptives in future.

Reproduction (2018) 155 347-359
\end{abstract}

\section{Introduction}

The mammalian epididymis provides a specific intra-luminal environment for the morphological and biochemical modifications needed to produce functionally mature spermatozoa (reviewed by Cooper 2007, Cornwall 2009, Dacheux \& Dacheux 2014). Mammalian spermatozoa undergo a series of morphological, physiological and biochemical posttranslational changes during sperm maturation in the epididymis, which result in their acquisition of motility and fertilizing capability (Phelps et al. 1990, Jones 1998, Srivastav 2000). The sperm plasma membrane undergoes extensive structural and biochemical modifications within the epididymis that lead to the acquisition of progressive motility, capacitation, zona pellucida binding and penetration and fertilizing capability. In particular, sperm must undergo a process known as capacitation that leads to hyperactivated motility and prepares the sperm for acrosomal exocytosis (Visconti et al. 2011).

Calcium signaling is critical for successful fertilization. Calcium channels play important roles in the process of fertilization and control sperm motility, chemotaxis toward the egg and the acrosome reaction (Chung et al. 2011, reviewed by Ren et al. 2010, Lishko \& Kirichok 2010, Sun et al. 2017). In spermatozoa, capacitation, hyperactivation of motility and the acrosome reaction are all mediated by increases in intracellular $\mathrm{Ca}^{2+}$ through CatSper, which are expressed exclusively in spermatogenic cells in testis. These specifically traffic to membranes of the developing sperm flagellum and play important roles in sperm motility and male fertility (Ren et al. 2001, reviewed by Navarro et al. 2008, Sun et al. 2017). CatSper is a heterotetrameric $\mathrm{Ca}^{2+}$ channel required for the hyperactivated motility of spermatozoa and male fertility (Qi et al. 2007, reviewed by Navarro et al. 2008, Lishko et al. 2012, Sun et al. 2017). The CatSper channel complex contains four pore-forming $\alpha$ subunits (CatSper1-4) and five accessory subunits called $\beta, \delta, \varepsilon, \gamma$ and $\zeta$ (Chung et al. 2017, reviewed by Navarro et al. 2008, Sun et al. 2017). The involvement of several subunits makes the channel complex, which seems to be required for its functional co-ordination, localization to the flagella and sensitivity to intracellular $\mathrm{pH}$, progesterone, other 
proteins and cell-signaling molecules and activators (reviewed by Benoff et al. 2007, Navarro et al. 2008, Ren \& Xia 2010, Darszon et al. 2011, Lishko et al. 2012, Sun et al. 2017).

Defects in the primary $\mathrm{pH}$-sensitive cationic calcium channel of sperm (CatSper) were shown to result in complete male infertility without other apparent defects in phenotype. The absence of CatSper channels was shown to cause male infertility in mice (Qi et al. 2007, Hildebrand et al. 2010, Chung et al. 2011), which is primarily because of the inability of sperm to hyperactivate. Mutation or absence of some ion channels directly affects male fertility (Carlson 2003, Smith et al. 2013), and lack of expression/mutation or disruption of any of the four CatSper genes leads to complete male infertility in both human and mice. Targeted disruption of CatSper1 (Ren et al. 2001), CatSper2 (Quill et al. 2003), CatSper3 or CatSper4 (Jin et al. 2007) each produced male infertility in mice. Despite the restricted localization of CatSpers to testicular, epididymal and ejaculated spermatozoa and their unique structure with vital role in male fertility, very little is known about the pharmacological targeting of the CatSper channel imposing a selective late-stage block to fertility (Carlson et al. 2009, Mannowetz et al. 2017, Wang et al. 2017). Carlson et al. (2009) have identified HC-056456 as a blocker of CatSper channel activity and further demonstrated that pharmacologic blockade of the CatSper channels not only prevents the development of sperm-hyperactivated motility but also causes a reversible loss of flagellar waveform asymmetry to pre-hyperactivated sperm.

The process of sperm maturation in the epididymis has been an advantageous post-testicular target for the development of safe, rapid and reversible male contraceptive. Some processes of epididymal sperm maturation, such as the initiation of progressive motility can be selectively interrupted, which induces dysfunction of sperm fertilization and male infertility. Several antifertility compounds are shown to interfere with epididymal function including a dual $5 \alpha$-reductases inhibitor Dutasteride (PNU157706) and Nifedipine, a calcium channel blocker. Dutasteride is a novel dual $5 \alpha$-reductase inhibitor used for the potential treatment of benign prostatic hyperplasia. This compound is of express interest as it inhibits both isoforms of $5 \alpha$-reductase enzyme (di Salle et al. 1998) and adversely affects sperm maturation and fertility (Henderson et al. 2004, 2006, Henderson \& Robaire 2005, Robaire \& Henderson 2006). Nifedipine, also known as calcium channel blocker (CCB), is an approved drug for high blood pressure and appears to have reversible antifertility effect on males showing functional defects in spermatozoa (Lee et al. 2006, Morakinyo et al. 2009). The antifertility effects of Nifedipine and similar CCBs are well understood in both in vitro experiments (Kanwar et al. 1993) and in vivo studies (Morakinyo et al. 2009,
Lee et al. 2011). However, little investigation on effect of male antifertility agents on CatSper gene expression in the epididymis and epididymal spermatozoa of mice has been conducted. Therefore, our objective in this study was to use real-time q-PCR analysis for CatSper gene expression in the epididymis and epididymal spermatozoa of BALB/c mice during the process of sperm maturation after treatment with antifertility agents such as dual $5-\alpha$ reductase inhibitor Dutasteride and CCB Nifedipine.

\section{Materials and methods}

\section{Materials}

Dutasteride (AVODART) was obtained from GlaxoSmith Kline Pharmaceuticals, Mumbai, India. Nifedipine (N6792, purity 99\%) was obtained from Sigma-Aldrich. TRIzol reagent was from Invitrogen, Superscript II reverse transciptase from GibcoBRL and Ex Taq DNA polymerase from TaKaRa. All other chemicals or reagents were obtained from Sigma-Aldrich, Invitrogen or otherwise mentioned in the text.

\section{Animals}

Young adult BALB/C male mice (2-3 months old, weighing 25-30 g) were bred and maintained in conditions with free access to water and food in the animal facility of CSIR-Central Drug Research Institute (CDRI), Lucknow, India. All protocols and experimental procedures for the use of animals in this study were performed with prior approval of the Institutional Animal Ethics Committee. The animals were housed in climate $\left(23 \pm 2^{\circ} \mathrm{C}, \mathrm{RH}: 60 \%\right)$ and photoperiod (12-h light-12-h darkness cycles) controlled animal quarters.

\section{Study design}

Thirty mice were divided into three different groups with $n=10$ in each group. The doses were selected carefully from the available literature.

\section{Control group}

\section{DS-treated group}

Mice receiving Dutasteride 'AVODART' ( $5 \mathrm{mg} / \mathrm{kg}$ orally for 15 days).

\section{NF treated group}

Mice receiving Nifedipine dissolved in sesame oil $(20 \mathrm{mg} / \mathrm{kg}$ orally for 15 days).

\section{Tissue collection}

After the last oral feeding on day 16 , mice were rapidly killed by cervical dislocation and testes, epididymides, seminal vesicles (SV) and ventral prostate (VP) were dissected out. The organs were cleared free of fat and connective tissues by washing in ice-cold sterile physiological saline $(0.9 \% \mathrm{w} / \mathrm{v})$, dried 
briefly and weighed on electronic balance (Afcoset, Mumbai, India; Model ER-120 A). The caput and cauda epididymides were divided and subjected to tissue fixation for histological examination or were immediately cryostored in liquid nitrogen for subsequent RNA extraction and RT-qPCR analysis. In another set of experiment, epididymal spermatozoa were collected from caput and cauda epididymides and subjected either to sperm motility, count and morphology examination or were immediately cryostored in liquid nitrogen for subsequent RNA extraction and RT-qPCR analysis.

\section{Histological study}

Testis, caput and cauda epididymides of control and treated mice were fixed in Bouin's fluid ( $2 \mathrm{~h}$ ) and serial sections of $5 \mu \mathrm{m}$ thickness were stained with Harris Hematoxylin and Eosin solution as described earlier (Srivastav et al. 2010). Images were analyzed and recorded using BX 60 Olympus microscope equipped with a digital imaging camera (DP-12) with the aid of the Micro Image Lite software 4.0 (Olympus).

\section{Sperm preparation}

Spermatozoa from the caput and cauda epididymides were obtained by mincing the segments in Tyrode's solution without sodium bicarbonate containing $1.0 \mathrm{mmol} / \mathrm{L}$ sodium pyruvate, $9.0 \mathrm{mmol} / \mathrm{L}$ sodium lactate $(\mathrm{pH} 7.6)$ and $5 \%(\mathrm{w} / \mathrm{v})$ BSA. The sperm preparations were incubated at $37^{\circ} \mathrm{C}$ for $10 \mathrm{~min}$ in $\mathrm{CO}_{2}$ incubator. The sperm was gently filtered through nylon gauze, centrifuged at $500 \mathrm{~g}$ for $10 \mathrm{~min}$ and were resuspended in $1 \mathrm{~mL}$ fresh Tyrode's solution. An aliquot of the sperm preparation was analyzed for sperm concentration, progressive motility, morphology and vitality, and the remaining fraction was processed for sperm mRNA isolation.

\section{Sperm motility, count and morphology}

Ten microliters of sperm fraction was placed on a pre-warmed slide with pre-warmed cover slip and examined quickly for sperm motility. The slides were visualized at $200 \times$ with a temperature-controlled $\left(37^{\circ} \mathrm{C}\right)$ phase-contrast BX 60 Olympus microscope equipped with a digital imaging camera (DP-12) and Micro Image Lite software 4.0 (Olympus). At least four fields were evaluated per group. Spermatozoa from caput and cauda epididymides were counted using Neubauer's hemocytometer. For sperm morphology, spermatozoa were collected immediately after killing of mice by flushing the vas deferens with phosphate-buffered saline ( $\mathrm{pH} 7.2)$, and a drop was smeared on a pre-warmed slide with pre-warmed cover slip. The slides were visualized at $1000 \times$ with a temperaturecontrolled $\left(37^{\circ} \mathrm{C}\right)$ phase-contrast BX 60 Olympus microscope as described earlier.

\section{Fertility study}

Fertility testing of male mice from each group was performed during the last week of the treatment period on days 10-15. The male mice $(n=6)$ were cohabitated overnight with proestrous females in a ratio of $1: 2$. Positive mating was confirmed by vaginal plug and presence of sperm in the vaginal smear. Mated females were separated and maintained in individual cages to record the number of pregnant females for fertility index and the number of live implantations on day 15 post coitum in pregnant females.

\section{RNA extraction}

The sperm fractions were purified using a discontinuous Percoll gradient (2 layers comprising of 45\% and 90\% v/v) in Ham's F10 medium (Sigma) as described earlier (Srivastav et al. 2010) to rule out the possibility of contamination by residual cells. After centrifugation $\left(20 \mathrm{~min}\right.$ at $500 \mathrm{~g}, 25^{\circ} \mathrm{C}$ ), spermatozoa were collected from under layer of $90 \%$ Percoll, and the washed sperm pellet ( $>80 \%$ motile) was resuspended in ice-cold PBS and immediately frozen in liquid nitrogen.

For RNA extraction, the total RNA from the liquid nitrogenfrozen epididymal spermatozoa, frozen epididymides and testis were extracted with TRIzol reagent (Invitrogen) according to the manufacturer's instructions. The purity of total RNA was checked spectrophotometrically at 260 and $280 \mathrm{~nm}$. A minimum optical density (OD 260/280) ratio 1.80 was selected for the following real-time reverse-transcriptase polymerase chain reaction (RT-PCR).

\section{Real-time $q P C R$}

Quantitative real-time polymerase chain reaction with SYBR green chemistry was used to perform quantitative determination of mRNA levels of CatSper1-4 genes from Dutasteride- and Nifedipine-treated mice. Total RNA (1.0 mg) for epididymis and testis or $0.5 \mathrm{mg}$ for spermatozoa) was reverse transcribed to complementary DNA with the Revert Aid cDNA synthesis kit (Fermentas, Austin, TX, USA) using $2 \mu \mathrm{g}$ of total RNA in $20 \mu \mathrm{L}$ reaction volume. For quantitative real-time polymerase chain reaction (qPCR), the CDNA was amplified by PCR using selected primers in LightCycler 480 (Roche Molecular Biochemicals, Indianapolis, IN, USA) RealTime PCR System with pre-installed software. The design of sense and antisense oligonucleotide primers was based on published cDNA sequences using the Universal Probe Library (Roche Diagnostics). To eliminate a possible contamination by genomic DNA, primers were chosen in different exons. Primer sequence of various genes used for $\mathrm{qPCR}$ is given in Table 1 . Briefly, a $20 \mu \mathrm{L}$ total PCR reaction was used that included, $1 \mu \mathrm{g}$ of CDNA, $1 \mu \mathrm{L}$ of forward primer, $1 \mu \mathrm{L}$ of reverse primer, $10 \mu \mathrm{L}$ SYBR Green and $7 \mu \mathrm{L}$ RNAase-free water. The real-time-PCR cycling conditions were $95^{\circ} \mathrm{C}$ for $15 \mathrm{~s}, 60^{\circ} \mathrm{C}$ for $30 \mathrm{~s}, 72^{\circ} \mathrm{C}$ for $30 \mathrm{~s}$ followed by 40 cycles. The temperature for melting curve program was determined between $60^{\circ} \mathrm{C}$ and $95^{\circ} \mathrm{C}$. The housekeeping gene, glyceraldehyde-3-phosphate dehydrogenase (Gapdh), was used as the internal control in this study. We studied the fold change in genes of interest as compared to control values normalized to reference gene Gapdh. GAPDH has consistently been used as an internal control to normalize many genes including CatSper gene expression (Kim et al 2015, Jahromi et al 2014, Gong et al 2014, Park et al. 2014). Also, several previous studies have used GAPDH as house keeping control for normalization in 
relative mRNA expression analysis while treating with DS (Schmidt et al. 2009) and NF (Iwai et al. 2011).

Relative quantification of the expression of genes was calculated using the $2 \wedge \mathrm{DDC}_{\mathrm{T}}$ method (Livak \& Schmittgen 2001) where $C_{T}$ is the cycle threshold. The $D C_{T}$ was the difference between the PCR product and its internal control GAPDH.

$$
\begin{gathered}
\text { Ratio }=\frac{\left(E_{\text {target }}\right) \Delta C_{\mathrm{T}_{\text {reference }}}}{\left(E_{\text {target }}\right) \Delta C_{\mathrm{T}_{\text {reference }}}} \\
C_{\mathrm{T}_{\text {target=control }}} C_{\mathrm{T}}-C_{\mathrm{T}_{\text {treatment }}} \\
\Delta C_{\mathrm{T}_{\text {reference }}}=C_{\mathrm{T}_{\text {control }}}-C_{\mathrm{T}_{\text {treatment }}} \\
\text { Ratio }=2^{-\Delta \Delta \mathrm{Ct}} \text { Equation 2 }
\end{gathered}
$$

Whereas

$$
\Delta \Delta C_{\mathrm{T}}=\Delta C_{\mathrm{T}_{\text {reference }}}-\Delta_{\mathrm{t}} C_{\mathrm{T}_{\text {target }}}
$$

\section{Statistical analysis}

Data are expressed as mean \pm S.E.M. The data obtained in experiments with multiple treatments were subjected to oneway ANOVA followed by post hoc Newman-Keuls multiple comparison test of significance using GraphPad Prism 3.02 software. Qualitative observations were represented following assessments made by three individuals blinded to the experimental designs.

\section{Results}

\section{Body and reproductive organ weights}

In the present study, no significant change in final body weights of male mice treated with DS at $5 \mathrm{mg} / \mathrm{kg}$ for 15 days were observed compared to controls. NF at $20 \mathrm{mg} / \mathrm{kg}$ for 15 days slightly reduced the body weights of treated male mice (Table 2). In the present study, no significant changes were observed in testis weight of male BALB/c mice treated with DS or NF compared to controls (Table 2).

Total epididymis weight was significantly reduced by DS $\left(P<0.001^{* * *}\right)$ and reduced non-significantly by NF vs control mice in order of DS $(-27.41 \%)>N F$
$(-8.66 \%)$ as shown in Table 2 . However, significant $\left(P \leq 0.05^{*}\right)$ differences were noted in total epididymis weights between intra-groups DS vs NF (Table 2). Both DS and NF reduced the weights of caput and cauda epididymides when compared with control mice (Table 2). Caput epididymis was reduced significantly by DS $\left(P<0.001^{* * *}\right)$ and less significantly by NF $\left(P \leq 0.05^{*}\right)$ vs control in order of DS $(-34.62 \%)>N F$ $(-16.19 \%)$ while cauda epididymis weight was reduced significantly only by DS $\left(P<0.01^{* *}\right)$ and nonsignificantly by NF $(-8.73 \%)$. However, significant $\left(P<0.01^{* *}\right)$ differences in caput epididymis weights and non-significant differences in cauda epididymis weights were observed between intra-groups DS vs NF.

SV and VP weights were reduced both by DS and NF in treated mice (Table 2). SV weight was highly significantly $\left(P<0.001^{* * *}\right)$ reduced by DS $(-54.84 \%)$ and less significantly $\left(P<0.01^{* *}\right)$ by NF $(-24.44 \%)$. Similarly, VP weight was highly significantly $\left(P<0.001^{* * *}\right)$ reduced by DS $(-52.40 \%)$ and nonsignificantly by NF $(-18.31 \%)$. However, significant $\left(P<0.01^{* *}\right)$ differences were noted in SV and VP weights between DS- and NF-treated mice.

\section{Testis histology}

Testis of control mice (Fig. 1A) showed normal seminiferous tubules with normal Sertoli and germ cells at various stages of spermatogenic cycle covering complete cycle. The Leydig cells in the interstitium showed normal morphology. Testis of mice treated with Dutasteride $(5 \mathrm{mg} / \mathrm{kg} \times 15$ days $)$ showed normal germ cells, Sertoli cells and Leydig cells (Fig. 1B). Testis of mice treated with Nifedipine $(20 \mathrm{mg} / \mathrm{kg} \times 15$ days $)$ showed reduced sperm formation in seminiferous tubules with normal Sertoli and Leydig cells (Fig. 1C).

\section{Epididymal histology}

The caput (Fig. 1D) and cauda (Fig. 1G) epididymides

\begin{tabular}{|c|c|c|c|c|c|}
\hline Target genes & Sequence $\left(5^{\prime}-3^{\prime}\right)$ & Amplicon size (bp) & GC $(\%)$ & Molecular weight $(\mathrm{g} / \mathrm{mol})$ & Accession number \\
\hline CatSper1-LP & CTGAGCTAGAGATCCGAGGTG & 93 & 57 & 6511 & AF407332 \\
\hline CatSper1-RP & CAATTAGCTTGAGGACTGCTTCT & & 43 & 7029 & \\
\hline CatSper2-LP & TTTGTGCTGATGGTTGAAATAGA & 106 & 35 & 7148 & AF411816 \\
\hline CatSper2-RP & TGAAGCTAAGCAAGATGAACCA & & 41 & 6785 & \\
\hline CatSper3-LP & GСТTTСТTTAСТСТСТTCAGTTTGG & 91 & 40 & 7571 & АК014942 \\
\hline CatSper3-RP & CCCGGCTCACAGTAAACTTC & & 55 & 6022 & \\
\hline CatSper4-LP & TCCGAGAGGAACTCAACATGA & 92 & 48 & 6448 & AK077145 \\
\hline CatSper4-RP & GGAGGTATACTTGTGTAGGATCACATT & & 41 & 8369 & \\
\hline Gapdh-LP & TTTGATGTTAGTGGGGTCTCG & 62 & 47.6 & 6514.2 & NM_017008 \\
\hline Gapdh-RP & AGCTTGTCATCAACGGGAAG & & 50 & 6166.1 & \\
\hline
\end{tabular}
of control mice showed normal morphology, tubular diameter and high sperm density in epididymal lumen. DS treatment at $5 \mathrm{mg} / \mathrm{kg}$ for 15 days caused marked

Table 1 Primer sequence of various genes used for qPCR.

$\mathrm{LP}$, left primer; RP, right primer. 
Table 2 Effect of DS and NF treatments on the body and reproductive organ weights of adult male BALB/c mice treated for 15 days.

\begin{tabular}{|c|c|c|c|c|c|c|c|c|}
\hline \multirow[b]{3}{*}{ Groups } & \multicolumn{2}{|c|}{ Body weights (g) } & \multicolumn{6}{|c|}{ Absolute organ weights (mg) } \\
\hline & \multirow[b]{2}{*}{ Initial } & \multirow[b]{2}{*}{ Final } & \multirow[b]{2}{*}{ Testis weight } & \multicolumn{3}{|c|}{ Epididymis } & \multirow[b]{2}{*}{ SV weight } & \multirow[b]{2}{*}{ VP weight } \\
\hline & & & & Total & Caput & Cauda & & \\
\hline Control & $27.23 \pm 0.31$ & $29.26 \pm 0.50$ & $110.58 \pm 6.08$ & $31.62 \pm 1.18$ & $15.67 \pm 0.55$ & $12.43 \pm 0.53$ & $188.08 \pm 15.91$ & $4.04 \pm 0.27$ \\
\hline DS ( $5 \mathrm{mg} / \mathrm{kg} \times 15$ days) & $27.31 \pm 0.32$ & $24.97 \pm 0.76^{* * *}$ & $101.22 \pm 6.63$ & $22.95 \pm 0.66^{* * *}$ & $10.24 \pm 0.44^{* * *}$ & $9.05 \pm 0.45^{* *}$ & $84.92 \pm 4.64^{* * *}$ & $1.92 \pm 0.19^{* * *}$ \\
\hline $\mathrm{NF}(20 \mathrm{mg} / \mathrm{kg} \times 15$ days $)$ & $27.32 \pm 0.39$ & $25.83 \pm 0.38^{* *}$ & $104.45 \pm 5.11$ & $28.88 \pm 2.25$ & $13.13 \pm 0.89^{*}$ & $11.34 \pm 0.87$ & $142.1 \pm 11.95$ & $3.31 \pm 0.28$ \\
\hline DS vs NF & & DS vs NF ns & DS vs NF ns & DS vs NF+ & DS vs $\mathrm{NF}^{++}$ & DS vs NF ns & DS vs $\mathrm{NF}^{++}$ & DS vs $\mathrm{NF}^{+++}$ \\
\hline
\end{tabular}

Values are expressed as means \pm S.E.M. $(n=10)$.

Levels of significance: ${ }^{*} P<0.05 ;{ }^{* *} P<0.001 ;{ }^{* * *} P<0.0001$ compared with control group; DS vs NF levels of significance: ${ }^{+} P<0.05$; ${ }^{++} P<0.001$; ${ }^{+++} P<0.0001$.

decline in epididymal tubular size and luminal sperm density in both caput (Fig. 1E) and cauda (Fig. 1H) epididymides. On the contrary, NF at $20 \mathrm{mg} / \mathrm{kg}$ for 15 days showed normal epididymal tubular size with slightly reduced sperm density in both caput (Fig. 1F) and cauda (Fig. 1I) epididymides.

\section{Sperm morphology}

Analysis of spermatozoa from the caput (Fig. 2A) and cauda (Fig. 2D) epididymides of control mice showed normal morphology depicting head, midpiece and long tail observed under phase-contrast microscope. As observed under phase-contrast microscopy, the number of abnormal sperm was higher in both DS-treated caput (Fig. 2B) and cauda (Fig. 2E) epididymides as compared to controls. Similar observations were recorded in NF-treated caput (Fig. 2C) and cauda (Fig. 2F) epididymides. The percentage of highly agglutinated, tailless, decapitated and broken spermatozoa exhibiting other abnormalities like swollen heads and coiled tails with significant increase in flagellar angulation were higher in mice treated both with DS and NF.

\section{Sperm count}

Spermatozoa collected from caput and cauda epididymides of control mice showed normal sperm count and motility as shown in Table 3. Spermatozoa collected from caput epididymis of treated mice exhibited significant decline in sperm count by DS $\left(P<0.001^{* * *}\right)$ and non-significantly by NF as compared to controls in order of DS $(-52.42 \%)>N F(-19.79 \%)$. Likewise, sperm count of cauda epididymis of treated

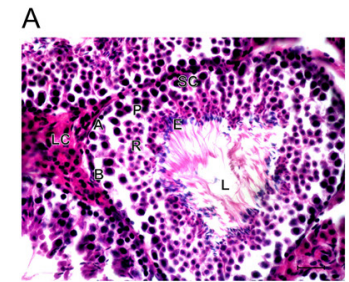

$\mathrm{F}$

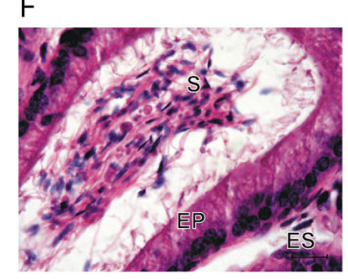

B

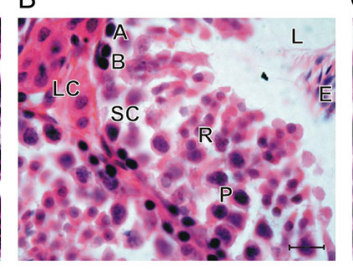

G

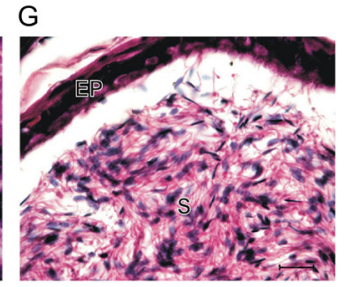

C

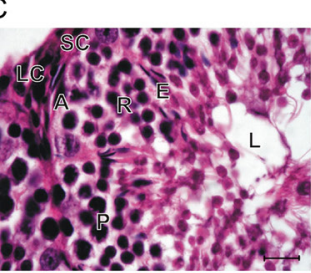

$\mathrm{H}$

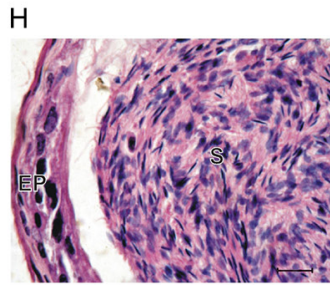

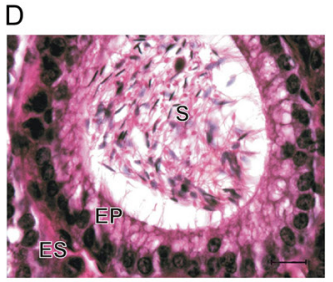

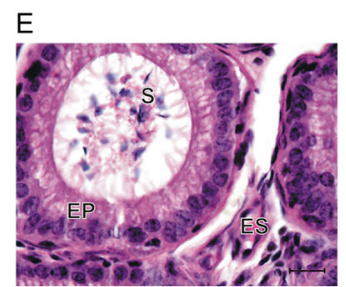

।

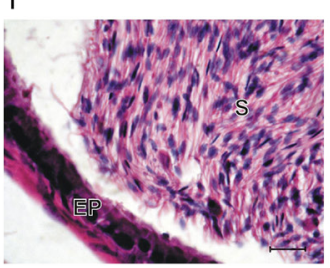

Figure 1 (A) Histology of testis of control mice showing normal spermatogenesis. A-spermatogonia, B-spermatogonia, P-pachyetene spermatocytes, R-round spermatids, E-elongated spermatids/spermatozoa, SC-Sertoli cells, LC-Leydig cells and L-Lumen. Hematoxylin (HE)stained $\times 400$ magnification (scale bar $=55 \mu \mathrm{m}$ ). (B) Histology of testis of mice treated with Dutasteride (DS) at $5 \mathrm{mg} / \mathrm{kg}$ orally for 15 days Hematoxylin (HE) stained $\times 1000$ magnification (scale bar $=22 \mu \mathrm{m}$ ). (C) Histology of testis of mice treated with Nifedipine (NF) at $20 \mathrm{mg} / \mathrm{kg}$ orally for 15 days. Hematoxylin (HE) stained $\times 1000$ magnification (scale bar $=22 \mu \mathrm{m}$ ). (D) Histology of caput epididymis of control mice. EP, epididymal epithelium; ES, epididymal stroma; S, luminal spermatozoa. Hematoxylin (HE) stained $\times 1000$ magnification (scale bar=22 $\mu$ m). (E) Histology of caput epididymis of mice treated with Dutasteride (DS) at $5 \mathrm{mg} / \mathrm{kg}$ orally for 15 days. Hematoxylin (HE) stained $\times 1000$ magnification (scale bar $=22 \mu \mathrm{m}$ ). (F) Histology of caput epididymis of mice treated with Nifedipine (NF) at $20 \mathrm{mg} / \mathrm{kg}$ orally for 15 days. Hematoxylin (HE) stained $\times 1000$ magnification (scale bar $=22 \mu \mathrm{m}$ ). (G) Histology of cauda epididymis of control mice. EP, epididymal epithelium; ES, epididymal stroma; S, luminal spermatozoa. Hematoxylin (HE) stained $\times 1000$ magnification (scale bar $=22 \mu \mathrm{m})$. (H) Histology of cauda epididymis of mice treated with Dutasteride (DS) at $5 \mathrm{mg} / \mathrm{kg}$ orally for 15 days. Hematoxylin (HE) stained $\times 1000$ magnification (scale bar $=22 \mu \mathrm{m}$ ). (I) Histology of cauda epididymis of mice treated with Nifedipine (NF) at $20 \mathrm{mg} / \mathrm{kg}$ orally for 15 days. Hematoxylin (HE) stained $\times 1000$ magnification (scale bar $=22 \mu \mathrm{m}$ ). 
A

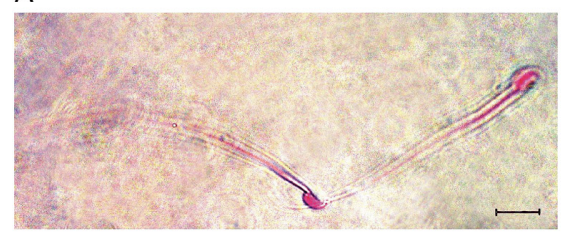

D

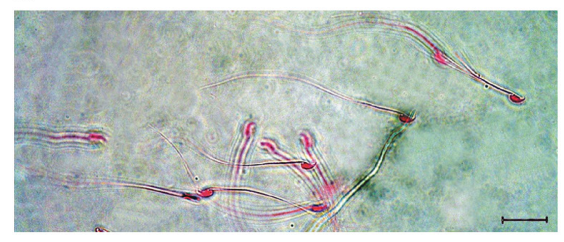

B

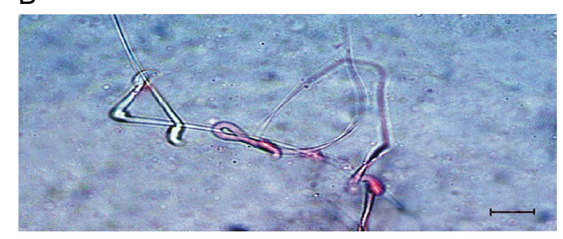

E

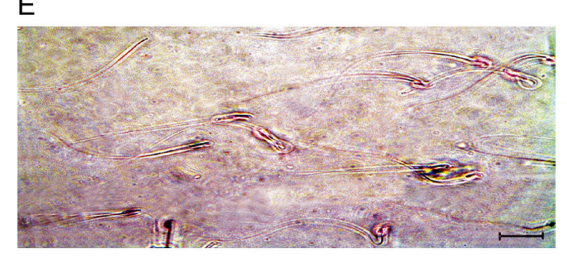

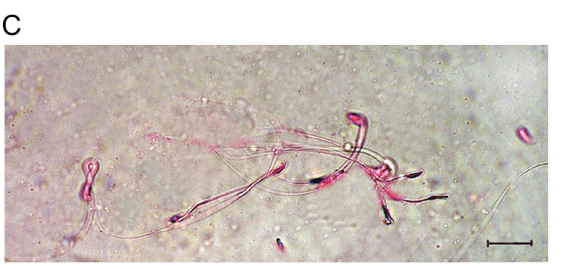

F

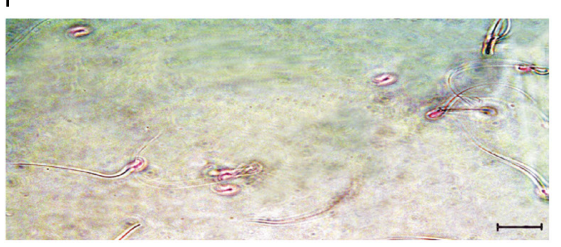

Figure 2 (A) Phase-contrast photograph showing morphology of sperm from caput epididymis of control mice. Eosin stained $1000 \times$ magnification (scale bar $=22 \mu \mathrm{m}$ ). (B) Phase-contrast photograph showing morphology of sperm from caput epididymis of mice treated with Dutasteride (DS) at $5 \mathrm{mg} / \mathrm{kg}$ orally for 15 days $(1000 \times)$ (scale bar $=22 \mu \mathrm{m})$. (C) Phase-contrast photograph showing morphology of sperm from caput epididymis of mice treated with Nifedipine (NF) at $20 \mathrm{mg} / \mathrm{kg}$ orally for 15 days $(1000 \times)$ (scale bar $=22 \mu \mathrm{m}$ ). (D) Phase-contrast photograph showing morphology of sperm from cauda epididymis of control mice. Eosin stained 1000× magnification (scale bar $=22 \mu \mathrm{m})$. (E) Phase-contrast photograph showing morphology of sperm from cauda epididymis of mice treated with Dutasteride (DS) at $5 \mathrm{mg} / \mathrm{kg}$ orally for 15 days (1000x) (scale bar $=22 \mu \mathrm{m}$ ). (F) Phase-contrast photograph showing morphology of sperm from cauda epididymis of mice treated with Nifedipine (NF) at $20 \mathrm{mg} / \mathrm{kg}$ orally for 15 days $(1000 \times)$ (scale bar $=22 \mu \mathrm{m})$.

mice exhibited significant decline in sperm count by DS $\left(P<0.001^{* *}\right)$ and slightly less significantly by NF $\left(P \leq 0.05^{*}\right)$ treatments as compared to controls in order of DS $(-68.46 \%)>N F(-38.59 \%)$.

\section{Sperm motility}

As shown in Table 3, sperm motility of caudal epididymal spermatozoa was significantly reduced by DS $\left(P<0.001^{* * *}\right)$ and less significantly by NF $\left(P<0.01^{* *}\right)$ vs control in order of DS $(-75.17 \%)>N F(-36.17 \%)$. Thus, DS caused higher reduction than NF in motility of caudal epididymal spermatozoa of treated mice.

\section{Fertility test and contraceptive efficacy}

As shown in Table 4, fertility trial during 10-15 days of treatment schedule culminated in normal pregnancy outcome in control animals where 11 mice mated out of 12 mice put for mating (evidenced by vaginal plug) and became pregnant (mating index: $91.6 \%$, fertility index $91.6 \%)$. The fertility of DS-treated mice $(5 \mathrm{mg} / \mathrm{kg} /$ day $\times 15$ days) was declined significantly as evidenced by
$100 \%$ reduction in fertility of treated males. The ability of males to mate was severely affected as evidenced by the observation that out of 12 mice put for mating, none of the DS-treated males mated with cohabitated females (mating index $0 \%$, fertility index $0 \%$ ). The fertility of NF treated mice $(20 \mathrm{mg} / \mathrm{kg} /$ day $\times 15$ days $)$ was also reduced where $8 / 12$ mice mated and $5 / 12$ became pregnant (mating index $66.6 \%$, fertility index $42.31 \%$ ). The mean number of live implantations observed on day 15 post coitum in pregnant females of NF-treated mice was reduced $(1.54 \pm 0.02)$ as compared to control mice $(6.84 \pm 0.650)$.

\section{Downregulation of the CatSper mRNAs in epididymis and testis of DS and NF-treated mice}

\section{Caput epididymis}

DS downregulated CatSper4 non-significantly slightly $(-8.25 \%)$ in caput epididymis of treated mice as compared to control mice (Fig. 3D). Similarly, NF caused significant downregulation of CatSper1 $(-95.60 \%$, $\left.P \leq 0.05^{*}\right)$ and CatSper4 (-93.76\%, $\left.P<0.0001^{* *}\right)$

Table 3 Effect of DS and NF treatments on sperm motility and sperm count of adult male mice treated for 15 days.

\begin{tabular}{|c|c|c|c|}
\hline \multirow[b]{2}{*}{ Groups } & \multirow{2}{*}{$\begin{array}{r}\text { Sperm motility (\%) } \\
\text { Cauda epididymis }\end{array}$} & \multicolumn{2}{|c|}{ Sperm count $\times 10^{6} / \mathrm{mL}$} \\
\hline & & Caput epididymis & Cauda epididymis \\
\hline Control & $70.5 \pm 6.16$ & $5.36 \pm 0.41$ & $7.57 \pm 0.62$ \\
\hline DS $(5 \mathrm{mg} / \mathrm{kg} \times 15$ days $)$ & $17.5 \pm 3.09 * * *$ & $2.75 \pm 0.22^{* * *}$ & $2.99 \pm 0.26^{* * *}$ \\
\hline $\mathrm{NF}(20 \mathrm{mg} / \mathrm{kg} \times 15$ days $)$ & $45 \pm 5.42^{* *}$ & $4.65 \pm 0.40$ & $5.84 \pm 0.68^{*}$ \\
\hline DS vs NF & DS vs $\mathrm{NF}^{++}$ & DS vs $\mathrm{NF}^{++}$ & DS vs $\mathrm{NF}^{+++}$ \\
\hline
\end{tabular}

Values are expressed as means \pm S.E.M. $(n=10)$.

Levels of significance: ${ }^{*} P<0.05 ;{ }^{* * P} P 0.001 ;{ }^{* * *} P<0.0001$ compared with control group; DS vs NF levels of significance: ${ }^{+} P<0.05 ;{ }^{++} P<0.001$; ${ }^{++} P<0.0001$. 
Table 4 Effect of DS and NF treatments on fertility of adult male mice treated for 5 days.

\begin{tabular}{|c|c|c|c|c|c|}
\hline & & & Mating index (\%) & Fertility index (\%) & $\begin{array}{l}\text { Implantation sites on day } \\
15 \text { pc }\end{array}$ \\
\hline Treatment groups & $\begin{array}{l}\text { No of males } \\
\text { put for } \\
\text { mating }\end{array}$ & $\begin{array}{l}\text { No of females } \\
\text { put for mating }\end{array}$ & $\begin{array}{c}\text { No of females mated/no } \\
\text { of females put for } \\
\text { mating }\end{array}$ & $\begin{array}{l}\text { No of pregnant females/no } \\
\text { of cohabitated females }\end{array}$ & $\begin{array}{l}\text { Implantation sites } \\
(\text { mean } \pm \text { S.E.M. })\end{array}$ \\
\hline Control & 6 & 12 & $11 / 12(91.6 \%)$ & $11 / 12(91.6 \%)$ & $6.84 \pm 0.650$ \\
\hline DS ( 5 mg/kg × 15 days) & 6 & 12 & 0 & 0 & 0 \\
\hline NF $(20 \mathrm{mg} / \mathrm{kg} \times 15$ days $)$ & 6 & 12 & $8 / 12(66.6 \%)$ & $5 / 12(42.31 \%)$ & $1.54 \pm 0.02$ \\
\hline
\end{tabular}

mRNAs (Fig. 3A and D). The downregulation of CatSper2 $(-98.72 \%)$ and CatSper3 (-95.88\%) mRNAs by NF was non-significant in caput epididymis of treated mice (Fig. 3B and C).

\section{Cauda epididymis}

Both DS and NF downregulated all four CatSper channels significantly $\left(P<0.001^{* * *}\right)$ in cauda epididymis of treated mice. There was statistically significant downregulation of the CatSper1 $(-93.77 \%)$, CatSper2 $(-96.18 \%)$, CatSper3 $(-98.47 \%)$ and CatSper4 $(-89.69 \%)$ mRNAs in cauda epididymis of DS-treated mice as compared to control mice. Likewise, NF caused statistically significant $\left(P<0.001^{* * *}\right)$ downregulation of the CatSper1 (-99.77), CatSper2 (-99.79\%), CatSper3 $(-99.81 \%)$ and CatSper4 (-98.75\%) mRNAs in cauda epididymis of treated mice (Fig. 3A, B, C and D).

\section{Testis}

DS caused slight non-significant downregulation $(-18.38 \%)$ of CatSper 1 mRNA, while NF caused nonsignificant downregulation of CatSper2 $(-23.18 \%)$ and CatSper3 $(-5.70 \%)$ mRNAs (Fig. 3A, B and C) in testis tissue of treated mice as compared to control mice.

\section{Caput vs cauda epididymis}

All four CatSper mRNAs including CatSper1, CatSper2, CatSper3 and CatSper4 were downregulated more severely in cauda epididymis by DS $(-98.572,-98.81$, -99.613 and $-88.77 \%)$ as well as by NF (-94.781, $-83.88,-95.77$ and $-80.27 \%$ ) treatments respectively as compared to caput epididymis in treated mice (Fig. 3A, B, C and D).

\section{Testis vs caput epididymis}

DS caused higher expressions of CatSper1 (4.35 times; 434.01\%), CatSper2 (2.079 times; 107.91\%) and CatSper3 (3.77 times; 277.81\%) mRNAs in caput epididymis as compared to testis in treated mice (Fig. 3A, B and C). However, CatSper4 mRNA was downregulated $(-20.57 \%)$ more severely in caput epididymis as compared to testis in treated mice (Fig. 3D). Likewise, NF downregulated CatSper1 (-97.66\%), CatSper2 (-98.28\%), CatSper3 (-95.34\%) and CatSper4 (-97.24\%) mRNAs more severely in caput epididymis as compared to testis in treated mice (Fig. 3A, B, C and D).

\section{Testis vs cauda epididymis}

The expressions of all four CatSper1-4 mRNAs including CatSper1 (-92.35\%), CatSper2 (-97.54\%), CatSper3 (-98.54\%) and CatSper4 (-91.08\%) were downregulated more severely by DS in cauda epididymis as compared to testis in treated mice (Fig. 3A, B, C and D). Likewise, NF downregulated more severely all four
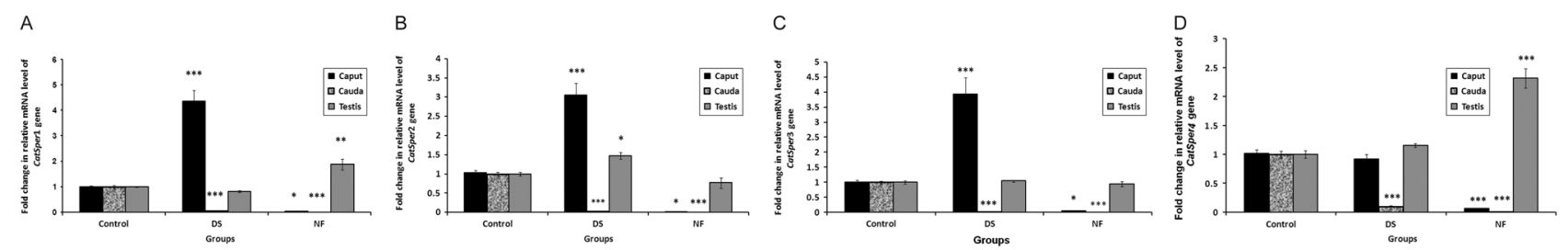

Figure 3 (A) Fold change in mRNA level of CatSper1 gene relative to GAPDH of caput, cauda epididymides and testis of control and treated BALB/c mice with Dutasteride (DS) at $5 \mathrm{mg} / \mathrm{kg}$ orally for 15 days and Nifedipine (NF) at $20 \mathrm{mg} / \mathrm{kg}$ orally for 15 days. Levels of significance: ${ }^{*} P<0.05 ;{ }^{* *} P<0.001 ;{ }^{* * *} P<0.0001$ compared with control group. (B) Fold change in mRNA level of CatSper2 gene relative to GAPDH of caput, cauda epididymides and testis of control and treated BALB/C mice with Dutasteride (DS) at $5 \mathrm{mg} / \mathrm{kg}$ orally for 15 days and Nifedipine (NF) at $20 \mathrm{mg} / \mathrm{kg}$ orally for 15 days. Levels of significance: ${ }^{*} P<0.05$; ${ }^{* *} P<0.001 ;{ }^{* * *} P<0.0001$ compared with control group. (C) Fold change in mRNA level of CatSper3 gene relative to GAPDH of caput, cauda epididymides and testis of control and treated BALB/C mice with Dutasteride (DS) at $5 \mathrm{mg} / \mathrm{kg}$ orally for 15 days and Nifedipine (NF) at $20 \mathrm{mg} / \mathrm{kg}$ orally for 15 days. Levels of significance: ${ }^{*} P<0.05 ;{ }^{* *} P<0.001 ;{ }^{* * *} P<0.0001$ compared with control group. (D) Fold change in mRNA level of CatSper4 gene relative to GAPDH of caput, cauda epididymides and testis of control and treated BALB/c mice with Dutasteride (DS) at $5 \mathrm{mg} / \mathrm{kg}$ orally for 15 days and Nifedipine (NF) at $20 \mathrm{mg} / \mathrm{kg}$ orally for 15 days. Levels of significance: ${ }^{*} P<0.05 ;{ }^{* *} P<0.001 ;{ }^{* * *} P<0.0001$ compared with control group. 
CatSper1 (-99.87\%), CatSper2 (-99.73\%), CatSper3 $(-99.8 \%)$ and CatSper4 (-99.46\%) mRNAs in cauda epididymis in treated mice as compared to testis (Fig. 3A, B, C and D).

\section{Upregulation of the CatSper mRNAs in epididymis and testis of DS and NF treated mice}

\section{Caput epididymis}

CatSper1 mRNA was upregulated significantly $\left(P<0.001^{* *}\right)$ by DS 4 times $(335.85 \%)$ in caput epididymis (Fig. 3A), CatSper2 was upregulated 3 times $(195.76 \%)$ significantly $\left(P<0.01^{* *}\right)$ by $\mathrm{DS}$ (Fig. 3B) and CatSper3 was up-regulated 3.93 times (269.27\%) in DS-treated mice (Fig. 3C) as compared to control mice, which was statistically highly significant $\left(P<0.001^{* * *}\right)$.

\section{Testis}

DS caused non-significant upregulation of CatSper2 $(47.56 \%)$, CatSper3 (4.23\%) and CatSper4 mRNAs $(15.52 \%)$ in testis (Fig. 3B, C and D) of treated mice as compared to control mice. Likewise, NF caused significant $\left(P<0.01^{* *}\right) \quad$ upregulation of CatSper 1 $(87.790 \%)$ and CatSper4 (128.71\%) mRNAs highly significantly $\left(P<0.001^{* * *}\right)$ in testis (Fig. 3A and D) of treated mice as compared to control mice.

\section{CatSper mRNA expressions of caput and cauda spermatozoa are downregulated by male antifertility agents DS and NF, known to inhibit fertility in rodents}

Downregulation of the CatSper1, 2 and 4 $m R N A s$ by caput spermatozoa

We identified a remarkable downregulation of CatSpers in the epididymal spermatozoa of mice treated with male antifertility agents DS and NF, known to inhibit fertility in rodents. CatSper $1 \mathrm{mRNA}$ (Fig. 4A) was downregulated both by DS $(-67.86 \%)$ and NF $(-60.69 \%)$ treatments significantly $\left(P<0.001^{* * *}\right)$, CatSper2 mRNA (Fig. 4B) was downregulated by DS $(-99.99 \%)$ and NF $(-98.17 \%)$ highly significantly $\left(P<0.001^{* * *}\right)$. Likewise, CatSper4 mRNA (Fig. 4D) was downregulated both by DS (-99.99\%) and NF $(-98.17 \%)$ in caput spermatozoa, which was statistically significant $\left(P<0.001^{* * *}\right)$.

\section{Upregulation of the CatSper3 mRNA in caput spermatozoa of DS- and NF-treated mice}

CatSper3 mRNA (Fig. 4C) was upregulated by DS $(316.36 \%)$ as well as by NF $(440.02 \%)$ in caput spermatozoa, which was statistically significant $\left(P<0.01^{* *}\right)$.

\section{Downregulation of the CatSper1-4 mRNAs by cauda spermatozoa}

Both DS and NF treatments downregulated all four CatSper1-4 mRNAs of spermatozoa from cauda epididymis. DS downregulated Catsper1 mRNA (-96.75\%), CatSper2 mRNA (-99.63\%), CatSper3 mRNA (-99.63\%) and CatSper4 mRNA (-89.82\%) significantly $\left(P<0.001^{* * *}\right)$. Likewise, NF treatment downregulated CatSper1 mRNA (-86.19\%), CatSper2 mRNA (-98.17\%), CatSper3 mRNA (-98.17\%) and CatSper4 mRNA $(-98.00 \%)$ significantly $\left(P<0.001^{* * *}\right)$ as shown in Fig. 4A, B, C and D.

\section{CatSper mRNA expressions are downregulated more severely in cauda sperm as compared to caput spermatozoa by antifertility agents}

We further found that CatSper mRNA expressions were downregulated more severely in cauda sperm as
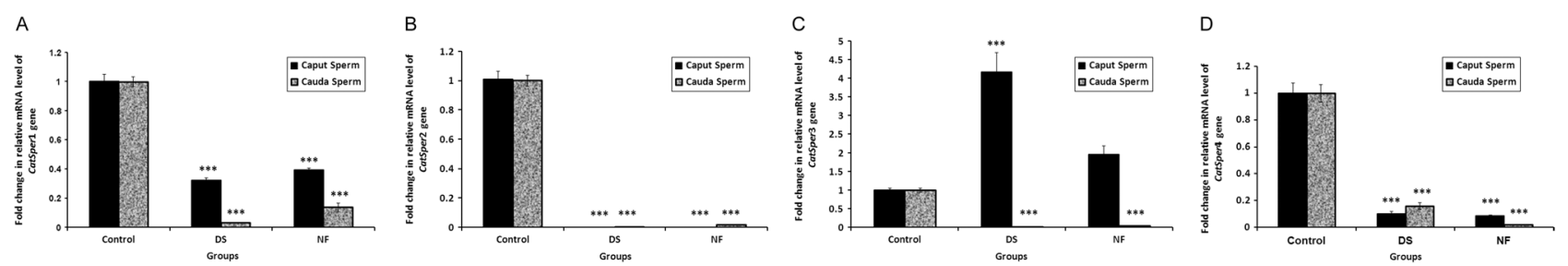

Figure 4 (A) Fold change in mRNA level of CatSper1 gene relative to GAPDH of caput and cauda epididymal spermatozoa of control and treated BALB/c mice with Dutasteride (DS) at $5 \mathrm{mg} / \mathrm{kg}$ orally for 15 days and Nifedipine (NF) at $20 \mathrm{mg} / \mathrm{kg}$ orally for 15 days. Levels of significance: ${ }^{*} P<0.05 ;{ }^{*} P<0.001 ;{ }^{* *} P<0.0001$ compared with control group. (B) Fold change in mRNA level of CatSper2 gene relative to GAPDH of caput and cauda epididymal spermatozoa of control and treated BALB/c mice with Dutasteride (DS) at $5 \mathrm{mg} / \mathrm{kg}$ orally for 15 days and Nifedipine (NF) at $20 \mathrm{mg} / \mathrm{kg}$ orally for 15 days. Levels of significance: ${ }^{*} P<0.05 ; * * P<0.001 ;{ }^{* * *} P<0.0001$ compared with control group. (C) Fold change in mRNA level of CatSper3 gene relative to GAPDH of caput and cauda epididymal spermatozoa of control and treated BALB/C mice with Dutasteride (DS) at $5 \mathrm{mg} / \mathrm{kg}$ orally for 15 days and Nifedipine (NF) at $20 \mathrm{mg} / \mathrm{kg}$ orally for 15 days. Levels of significance: $* P<0.05$; ${ }^{* *} P<0.001 ;{ }^{* * *} P<0.0001$ compared with control group. (D) Fold change in mRNA level of CatSper4 gene relative to GAPDH of caput and cauda epididymal spermatozoa of control and treated BALB/c mice with Dutasteride (DS) at $5 \mathrm{mg} / \mathrm{kg}$ orally for 15 days and Nifedipine (NF) at $20 \mathrm{mg} / \mathrm{kg}$ orally for 15 days. Levels of significance: ${ }^{*} P<0.05 ;{ }^{* *} P<0.001 ;{ }^{* * *} P<0.0001$ compared with control group. 
compared to caput spermatozoa by antifertility agents. CatSper 1 mRNA was downregulated more severely in cauda sperm as compared to caput spermatozoa in both DS- $(-89.913 \%)$ and NF (-64.86\%)-treated mice (Fig. 4A). Likewise, CatSper3 mRNA was downregulated more severely in cauda sperm by DS $(-99.72 \%)$ as well as by NF (-98.05\%)-treated mice (Fig. 4C). CatSper4 $m R N A$ was downregulated more severely in cauda sperm only by NF $(-76.52 \%)$ as compared to caput spermatozoa (Fig. 4D).

\section{Discussion}

The research on sperm ion channels is now focusing on the identification and characterization of genes and proteins. Sperm ion channels are difficult to study using conventional electrophysiological methods, because of their small size, complex geometry and motile nature. Although spermatozoa are in principle transcriptionally silent cells, certain mRNAs have been detected in these cells. It has been proposed that these RNAs are long lived and can be delivered to the egg for later expression. During the last decade, very few investigations have revealed the presence of a complex population of mRNA in mature spermatozoa of mammals (Dadoune et al. 2005), including the transcripts of some ion channels (Li et al. 2007, Wang et al. 2013). The mRNA of ion channels might be a feasible target to study ion channels in spermatozoa. Since these transcripts represent the remnants of stored mRNA from genes activated during spermatogenesis, the study of mRNAs in spermatozoa could reflect past events of spermatogenesis and/or spermiogenesis (reviewed by Darszon et al. 2011).

The epididymis, an androgen dependent organ, is the site of sperm maturation and storage. Several in vivo and in vitro studies have confirmed that it is not testosterone, but rather dihydrotestosterone (DHT), that is the main androgen acting in this tissue (Robaire \& Hamzeh 2011). $5 \alpha$-Reductases (types 1 and 2) are key enzymes in this tissue converting testosterone to dihydrotestosterone (DHT), the main androgen regulating epididymal functions. Both isoforms of $5 \alpha$-reductase, termed type 1 and type 2 (Andersson \& Russell 1990) have been identified in the epididymis and are reported to be differentially expressed along the tubule (Viger \& Robaire 1996).

In the present study, we performed quantitative realtime qPCR analysis for CatSpers 1-4 gene expressions in epididymis and epididymal spermatozoa of BALB/c mice during the process of sperm maturation after treatment with antifertility compounds such as dual 5 - $\alpha$-reductase inhibitor DS and CCB NF as positive control. We duplicated a male mice infertility model using DS $(5 \mathrm{mg} / \mathrm{kg} /$ day $\times 15$ days $)$ and NF $(20 \mathrm{mg} / \mathrm{kg} /$ day $\times 15$ days $)$ orally and evaluated changes in epididymal and testicular histology, sperm morphology, sperm count, motility, fertility index and CatSper gene expression in epididymis, testis and epididymal spermatozoa of BALB/C mice. The results showed that treatment with antifertility compounds DS and NF altered CatSper gene expression in epididymis and epididymal spermatozoa of mice during the process of sperm maturation.

The results of present study showed no significant changes in final body and testis weights with significant decreases in the weights of the DHT-dependent tissues such as epididymis, seminal vesicle or VP of male BALB/C mice treated with DS compared to controls. Our results are in agreement with findings of Henderson et al. (2004) and by Xie et al. (2016) in male rats after treatment with DS. The slight reduction in body weights of NF-treated mice is in accordance with results of Lee et al. (2006) in NF-treated ICR male mice. The less significant reduction by NF $\left(P \leq 0.05^{*}\right)$ in caput epididymis weight and nonsignificant reduction in cauda epididymis weight in present study is similar to findings of Morakinyo et al. (2009) in NF-treated male rats.

Sperm functions such as count and motility are key indices of male fertility as these are prime markers in testicular spermatogenesis and epididymal sperm maturation. The significant decline in sperm count of caput and cauda epididymides of DS- and NF-treated mice in current study are in accordance with findings reported by Henderson and Robaire (2005) and by Xie et al. (2016) in DS-treated rats. The reduced sperm count of cauda epididymis in NF-treated mice is in accordance with findings of Morakinyo et al. (2009) in NF-treated rats.

Our results indicated that sperm motility of cauda epididymal spermatozoa was significantly reduced both by DS and NF in order of DS $>N F$. The results are in accordance with the results of Henderson \& Robaire (2005) and Xie et al. (2016) who reported significant decrease in the percentage of motile and progressively motile sperm from the cauda epididymis of DS-treated rats. Likewise, Morakinyo et al. (2009) showed reduced sperm motility of cauda epididymal spermatozoa after NF treatment in rat. Previous reports showed that longterm treatment with the calcium channel blockers (CCBs), such as amlodipine and NF in hypertensive patients taking CCB not only inhibits spermatogenesis but also impairs sperm motility with reversible functional defects in sperm and inability to fertilize eggs (reviewed by Brezina et al. 2012).

In present study, the number of epididymal sperm showing abnormal morphology was higher in mice treated with DS and NF than in the controls. Majority of sperms exhibited abnormalities like swollen heads and coiled tails with significant increase in flagellar angulation. The percentage of highly agglutinated, tailless, decapitated, angulated and broken spermatozoa was common in treated mice both with DS and NF. Our findings parallel recent reports of Henderson \& Robaire (2005) and Xie et al. (2016). It is interesting that male infertility of apparently healthy animals able to mate has, 
in some instances, been correlated with spermatozoa displaying angulated flagella when released from the epididymis. Furthermore, several transgenic mice with normal sperm production that are infertile, also display flagellar angulation after epididymal transit, which is uncommon in normal mice. Angulation seems to result from permeability problems and often occurs at the end of the midpiece where the cytoplasmic droplet is located. The cytoplasmic droplet is a significant cytoplasm compartment and an important site for osmolyte and water permeation (reviewed by Darszon et al. 2011, Lishko et al. 2012). Henderson \& Robaire (2005) observed adversely affected morphology of cauda epididymal spermatozoa of DS-treated rats, the most prominent effect was a markedly elevated proportion of sperm that retained their cytoplasmic droplet.

The fertility of DS-treated male mice was declined significantly $(100 \%$ reduction) during fertility trial period (10-15 days of treatment schedule) in the current study. Likewise, the fertility of NF-treated mice ( $20 \mathrm{mg} /$ $\mathrm{kg} \times 15$ days) was also reduced as evidenced by significant decrease in the mating index $(66.6 \%)$ and fertility index $(42.31 \%)$ of females paired with NF-treated males. In the present study, the ability of DS-treated males to mate was severely affected as evidenced by the observation that none of the males mated with cohabitated female mice $(n=12)$ put for mating (mating index: $0 \%$; fertility index $0 \%$ ) suggesting that DS seemed to have an effect on the libido of treated mice. This is in contrast to no adverse effect reported on libido of adult Sprague-Dawley rats treated with DS either at $10 \mathrm{mg} / \mathrm{kg}$ dose (Henderson \& Robaire 2005) or at $40 \mathrm{mg} / \mathrm{kg}$ dose (Xie et al. 2016) for 28 consecutive days. The reduction in sperm count and motility and the presence of normal germ cells, Sertoli and Leydig cells in testis of DS-treated mice suggests that the primary mechanism of action of DS could be due to a direct effect on epididymis, SV and VP. This is supported by previous findings of Xie et al. (2016) who showed that Dutasteride could inhibit male rat fertility by interfering with epididymal tight junctions, which could influence blood-epididymis barrier and change the composition of epididymal luminal fluids. This could probably be affecting $5 \alpha$-reductase activity causing deficit of dihydrotestosterone (DHT) in DS-treated mice resulting in loss of libido of treated male mice in present study. Further studies are needed to confirm this hypothesis by measuring levels of DHT in serum or in seminal fluid of DS-treated male mice.

The results of present studies showed that treatment of adult male mice with DS has a highly segment-specific effect on epididymal CatSper $1-4$ gene expression as evidenced by significant $\left(P<0.001^{* * *}\right)$ upregulation of the CatSper1, CatSper2 and CatSper3 mRNAs and nonsignificant marginal upregulation of CatSper4 mRNA in caput epididymis of treated mice. All four CatSper mRNAs including CatSper1, CatSper2, CatSper3 and CatSper4 were downregulated more severely in cauda epididymis by DS as well as by NF treatments respectively as compared to caput epididymis in treated mice. Similarly, Henderson et al. (2004, 2006) showed segment-specific effect of DS (PNU157706) on epididymal gene expression and demonstrated that the expression of various region-specific genes in the epididymis was differentially affected by $5 \alpha$-reductase inhibition. They further showed that DHT-dependent regulation of gene expression involved components of different signaling pathways potentially involved in sperm-related functions in the rat epididymis.

In the present study, DS and NF upregulated CatSper3 mRNA significantly in caput spermatozoa of treated mice as compared to control mice. Likewise, NF caused significant upregulation of CatSper 1 and CatSper4 mRNAs in testis of treated mice. The results are similar to those of Wang et al. (2013) who demonstrated statistically significant upregulation of the CatSper1 channel associated with improved sperm motility in epididymal spermatozoa in cyclophosphamide (CP)induced asthenozoospermic rats by Sheng-Jing-San (SJS), a traditional Chinese medicine.

Similar upregulation of CatSper genes have been reported by Mohammadi et al. (2009), who showed that selenium (Se) treatment in aging NMRI male mice could upregulate the expression of CatSper1-4 genes and therefore resulted in elevation of sperm motility.

Most importantly, we identified remarkable downregulation of CatSper1-4 gene expressions in the epididymal spermatozoa of mice treated with male antifertility agents DS and NF. Both DS and NF downregulated CatSper1, CatSper2 and CatSper4 mRNAs in caput and cauda spermatozoa along with significant reduction in sperm motility in treated mice. We further found that CatSper 1 and CatSper3 mRNAs were downregulated more severely in cauda sperm of DS- and NF-treated mice while CatSper4 mRNA was downregulated severely by NF treatment in cauda sperm as compared to caput spermatozoa. The downregulation of CatSper1, 2 and 4 mRNAs in caput and cauda spermatozoa may likely contribute to impairment of sperm motility in treated mice with DS and NF. Considerable evidence has accumulated that downregulation of the CatSper 1 channel in epididymal spermatozoa likely contributes to the pathogenesis of asthenozoospermia in rat (Wang et al. 2013). Male mice deficient in the CatSper 1 gene have been shown to be impaired both in sperm motility and hyperactivation and they are completely infertile (Ren 2001, Carlson 2003). Wang et al. (2017) showed decrease in the motility, viability and acrosome reaction of sperm exposed to cadmium in vivo and in vitro, which were correlated with reduction in CatSper (sperm-specific $\mathrm{Ca}^{2+}$ current) in cadmium-treated mice. A significant reduction in the level of CatSper gene expression has also been found among patients who lack sperm motility (Nikpoor et al. 2004). Mutations in the CatSper1 channel protein have 
also been identified as a cause of human male infertility, probably resulting from diminished sperm motility (Avenarius 2009). Repression of the CatSper1 channel in sperm cells impairs $\mathrm{Ca}^{2+}$ signaling, which in turn causes impairment of the sperm motility and hyperactivation associated with asthenozoospermia and male subfertility (Espino 2009, Tamburrino et al. 2015). The results from various studies suggested a direct mechanism in which NF blocked and reduced the sperm calcium ion channels, thereby reducing ion influx and subsequently inhibiting the capacitation process and acrosomal reaction in mouse (Feng et al. 2003) and rat (Morakinyo et al. 2011b).

Various mechanisms of action of both DS and NF have been deciphered previously by other investigators in other rodent species which may be directly or indirectly influencing/regulating the CatSper gene expression in both epididymal sperm and epididymis of BALB/C mice. It is well accepted that $\mathrm{Ca}^{2+}$ signaling serves as a central regulator in many key activities of sperm cells including capacitation, the acrosome reaction and fertilization (Ho \& Suarez 2001, Costello 2009, Darszon et al. 2011). $\mathrm{Ca}^{2+}$ signaling affecting transmembrane fluxes of calcium ions leading to changes in intracellular calcium have been shown to be important for sperm motility initiation and regulation. DS has been shown to possibly affect essential processes such as luminal acidification, regulation of ion and fluid transport, protein processing and degradation, fatty acid and lipid metabolism and oxidative defense contributing to the formation of the optimal luminal microenvironment required for proper sperm maturation in epididymis (Henderson et al. 2004, 2006, Hamzeh \& Robaire 2010, Xie et al. 2016). Morakinyo et al. $(2011 a, b)$ demonstrated that while calcium antagonists (CA) exert their spermimmobilizing effect through calcium channel blockade, they may alternatively act through oxidative stressinduced cytotoxicity responsible for the adverse effects of decreased sperm count and motility ultimately leading to reduced fertility in rats. They further showed that Calcium channel blockers (CCBs) administration could cause inhibition of the acrosomal reaction in $\mathrm{NF}$ treated rats resulting from negative changes in the ionic environment and fluxes, especially of calcium ions, through the mammalian sperm membrane in rat epididymis resulting in loss of motility (Morakinyo et al. 2011a,b).

In conclusion, the antifertility changes induced by DS and NF in present study showed significant reduction in the epididymal sperm counts, motility and fertility of both DS and NF treated mice. These could partly be attributed to reduced weights of DHTdependent organs like epididymis, seminal vesicle and VP accompanied by reduced sperm count and motility, abnormal sperm morphology exhibiting swollen heads, coiled tails, flagellar angulation, tail-less, decapitated, broken and agglutinated spermatozoa in treated mice.
These changes were associated with downregulation/ upregulation of CatSper mRNAs in epididymal spermatozoa and epididymis of male BALB/c mice. These can be explained on the basis of interference with mechanisms affecting calcium ion signaling required for sperm activity ultimately resulting in changes in intracellular calcium levels finally affecting sperm maturation and fertility of male mice. Downregulation of CatSper genes by DS and by NF in caput and cauda epididymides and in caput spermatozoa observed in present studies needs to be studied in naïve mice to unravel whether it is via mutation or knockdown of the CatSper genes. Similarly, upregulation of CatSper genes through overexpression needs to be studied in depth to provide direct evidence that functional downregulation or upregulation of CatSper channels contributes to DS- and NF-induced antifertility in mice as suggested by Wang et al. (2013). Present studies provide new mechanisms of action of DS and NF for drug discovery of male antifertility compounds exploring novel avenues for identifying newer epididymal targets for developing new male contraceptives in future.

\section{Declaration of interest}

The authors declare that there is no conflict of interest that could be perceived as prejudicing the impartiality of the research reported.

\section{Funding}

Supported by Ministry of Health $(\mathrm{MOH})$ and Council of Scientific and Industrial Research (CSIR), Government of India.

\section{Acknowledgements}

The study was supported by Ministry of Health $(\mathrm{MOH})$, Council of Scientific and Industrial Research (CSIR), Government of India. The authors thank Kaynat Khan and Gaurav Swarnakar for providing valuable help during execution of experiments. The authors also thank Ravindranath S Londhe for expert scanning and reprography of images.

\section{References}

Aitken RJ, Baker MA, De Iuliis GN \& Nixon B 2010 New insights into sperm physiology and pathology. Handbook of Experimental Pharmacology 198 99-115. (https://doi.org/10.1007/978-3-642-02062-9_7)

Andersson S \& Russell DW 1990 Structural and biochemical properties of cloned and expressed human and rat steroid 5-alpha-reductases. PNAS 87 3640-3644. (https://doi.org/10.1073/pnas.87.10.3640)

Avenarius MR, Hildebrand MS, Zhang Y, Meyer NC, Smith LL, Kahrizi K, Najmabadi H \& Smith RJ 2009 Human male infertility caused by mutations in the CATSPER1 channel protein. American Journal of Human Genetics 84 505-510. (https://doi.org/10.1016/j.ajhg.2009.03.004)

Benoff S, Chu CC, Marmar JL, Sokol RZ, Goodwin LO \& Hurley IR 2007 Voltage-dependent calcium channels in mammalian spermatozoa revisited. Frontiers in Biosciences 12 1420-1449. (https://doi. org/10.2741/2158) 
Brezina PR, Yunus FN \& Zhao Y 2012 Effects of pharmaceutical medications on male fertility. Journal of Reproduction and Infertility 13 3-11.

Carlson AE, Ruth EW, Timothy Q, Dejian R, David EC, Bertil H, David LG \& Donner FB 2003 CatSper1 required for evoked Ca2+ entry and control of flagellar function in sperm. PNAS 100 14864-14868. (https://doi. org/10.1073/pnas.2536658100)

Carlson AE, Burnett LA, Camino D, Quill TA, Hille B, Chong JA, Moran MM \& Babcock DF 2009 Pharmacological targeting of native CatSper channels reveals a required role in maintenance of sperm hyperactivation. PLOS ONE 4 e6844. (https://doi.org/10.1371/journal. pone.0006844)

Chung JJ, Navarro B, Krapivinsky G, Krapivinsky L \& Clapham DE 2011 A novel gene required for male fertility and functional CATSPER channel formation in spermatozoa. Naure Communications 2 153. (https://doi. org/10.1038/ncomms1153)

Chung JJ, Miki K, Kim D, Shim SH, Shi HF, Hwang JY, Cai X, Iseri Y, Zhuang X and Clapham DE 2017 CatSperc regulates the structural continuity of sperm $\mathrm{Ca}^{2+}$ signaling domains and is required for normal fertility. eLife 6 e23082-e23106. (https://doi.org/10.7554/eLife.23082)

Cooper TG 2007 Sperm maturation in the epididymis: a new look at an old problem. Asian Journal of Andrology 9 533-539. (https://doi. org/10.1111/j.1745-7262.2007.00285.x)

Costello S, Michelangeli F, Nash K, Lefievre L, Morris J, MachadoOliveira G, Barratt C, Kirkman-Brown J \& Publicover S 2009 Ca2+stores in sperm: their identities and functions. Reproduction $\mathbf{1 3 8}$ 425-437. (https://doi.org/10.1530/REP-09-0134)

Cornwall GA 2009 New insights into epididymal biology and function. Human Reproduction Update 15 213-227. (https://doi.org/10.1093/ humupd/dmn055)

Dacheux JL \& Dacheux F 2014 New insights into epididymal function in relation to sperm maturation. Reproduction 147 R27-R42. (https://doi. org/10.1530/REP-13-0420)

Dadoune JP, Pawlak A, Alfonsi MF \& Siffroi JP 2005 Identification of transcripts by macroarrays, RT-PCR and in situ hybridization in human ejaculate spermatozoa. Molecular Human Reproduction 11 133-140. (https://doi.org/10.1093/molehr/gah137)

Darszon A, Nishigaki T, Beltran C \& Treviño CL 2011 Calcium channels in the development, maturation, and function of spermatozoa. Physiological Reviews 91 1305-1355. (https://doi.org/10.1152/physrev.00028.2010)

di Salle E, Giudici D, Radice A, Zaccheo T, Ornati G, Nesi M, Panzeri A, Delos S \& Martin PM 1998 PNU157706, a novel dual type I and II 5 alpha-reductase inhibitor. Journal of Steroid Biochemistry and Molecular Biology 64 179-186. (https://doi.org/10.1016/S0960-0760(97)00158-1)

Espino J, Mediero M, Lozano GM, Bejarano I, Ortiz A, Garcia JF, Pariente JA \& Rodriguez AB 2009 Reduced levels of intracellular calcium releasing in spermatozoa from asthenozoospermic patients. Reproductive Biology and Endocrinology 7 1-11. (https://doi.org/10.1186/1477-7827-7-11)

Feng HL 2003 Molecular biology of male infertility. Archives of Andrology 49 19-27. (https://doi.org/10.1080/01485010290031556-1)

Gong ZK, Wang SJ, Huang YQ, Zhao RQ, Zhu QF \& Lin WZ 2014 Identification and validation of suitable reference genes for RT-qPCR analysis in mouse testis development. Molecular Genetics and Genomics 289 1157. (https://doi.org/10.1007/s00438-014-0877-6)

Hamzeh M \& Robaire B 2010 Identification of early response genes and pathway activated by androgens in the initial segment and caput regions of the regressed rat epididymis. Endocrinology 151 4504-4514. (https:// doi.org/10.1210/en.2010-0023)

Henderson NA \& Robaire B 2005 Effects of PNU 157706, a dual 5 alpha-reductase inhibitor on rat epididymal sperm maturation and fertility. Biology of Reproduction 72 436-443. (https://doi.org/10.1095/ biolreprod.104.033548)

Henderson NA, Cooke GM \& Robaire B 2004 Effects of PNU157706, a dual $5 \alpha$-reductase inhibitor on gene expression in the rat epididymis. Journal of Endocrinology 181 245-261. (https://doi.org/10.1677/joe.0.1810245)

Henderson NA, Cooke GM \& Robaire B 2006 Region-specific expression of androgen and growth factor pathway genes in the rat epididymis and the effects of dual $5 \alpha$-reductase inhibition Journal of Endocrinology 190 779-791. (https://doi.org/10.1677/joe.1.06862)

Hildebrand MS, Avenarius MR, Fellous M, Zhang Y, Meyer NC, Auer J, Serres C, Kahrizi K, Najmabadi H \& Beckmann JS 2010 Genetic male infertility and mutation of CATSPER ion channels. European
Journal of Human Genetics 18 1178-1184. (https://doi.org/10.1038/ ejhg.2010.108)

Ho HC \& Suarez SS 2001 Hyperactivation of mammalian spermatozoa: function and regulation. Reproduction 122 519-526. (https://doi. org/10.1530/rep.0.1220519)

Iwai M, Kanno H, Inaba S, Senba I, Sone H, Nakaoka H \& Horiuchi M 2011 Nifedipine, a Calcium Channel Blocker, attenuated glucose intolerance and white adipose tissue dysfunction in type 2 diabetic KKAy mice. American Journal of Hypertension 24 169-174. (https://doi. org/10.1038/ajh.2010.198)

Jahromi MA, Movahedin M, Mazaheri Z, Amanlu M, Mowla SJ \& Batooli H 2014 Evaluating the effects of Escanbil (Calligonum) extract on the expression level of CatSper gene variants and sperm motility in aging male mice. International Journal of Reproductive Biomedicine 12 459-466.

Jin J, Jin N, Zheng H, Ro S, Tafolla D, Sanders KM \& Yan W 2007 CatSper3 and CatSper4 are essential for sperm hyperactivated motility and male fertility in the mouse. Biology of Reproduction 77 37-44. (https://doi. org/10.1095/biolreprod.107.060186)

Jones R 1998 Plasma membrane structure and remodelling during sperm maturation in the epididymis. Journal of Reproduction and Fertility Supplement 53 73-84. (https://doi.org/10.2164/jandrol.107.004259)

Kanwar U, Anand RJ \& Sanyal SN 1993 The effect of nifedipine a calcium channel blocker, on human spermatozoal functions. Contraception $\mathbf{4 8}$ 453-470. (https://doi.org/ 10.1016/0010-7824(93)90135-T)

Kim DR, Kim HY, Kim HY, Chang MS \& Park SK 2015 Trigonellae semen enhances sperm motility and the expression of the cation sperm channel proteins in mouse testes. Evidence-Based Complementary and Alternative Medicine 2015 8, Article ID 817324. (https://doi. org/10.1155/2015/817324)

Lee JH, Kim H, Kim DH \& Gye MC 2006 Effects of calcium channel blockers on the spermatogenesis and gene expression in peripubertal mouse testis. Archives of Andrology 52 311-318. (https://doi. org/10.1080/01485010600664024)

Lee JH, Ahn HJ, Lee SJ, Gye MC \& Min CK 2011 Effects of L- and T-type $\mathrm{Ca}^{2+}$ channel blockers on spermatogenesis and steroidogenesis in the prepubertal mouse testis. Journal of Assisted Reproduction and Genetics 28 23-30. (https://doi.org/10.1007/s10815-010-9480-x)

Li HG, Ding XF, Liao AH, Kong XB \& Xiong CL 2007 Expression of CatSper family transcripts in the mouse testis during post-natal development and human ejaculated spermatozoa: relationship to sperm motility. Molecular Human Reproduction 13 299-306. (https://doi.org/10.1093/ molehr/gam009)

Lishko PV \& Kirichok Y 2010 The role of hv1 and CatSper channels in sperm activation. Journal of Physiology 588 4667-4672. (https://doi. org/10.1113/jphysiol.2010.194142)

Lishko PV, Kirichok Y, Ren D, Navarro B, Chung JJ \& Clapham DE 2012 The control of male fertility by spermatozoan ion channels. Annual Review of Physiology 74 453-475. (https://doi.org/10.1146/annurevphysiol-020911-153258)

Livak KJ \& Schmittgen TD 2001 Analysis of relative gene expression data using real-time quantitative PCR and the $2 \wedge C_{T}$ method. Methods 25 402-408. (https://doi.org/10.1006/meth.2001.1262)

Mannowetz N, Millera MR \& Lishkoa PV 2017 Regulation of the sperm calcium channel CatSper by endogenous steroids and plant triterpenoids. PNAS 114 5743-5748. (https://doi.org/10.1073/pnas.1700367114/-/ DCSupplemental)

Mohammadi S, Movahedin M \& Mowla SJ 2009 Up-regulation of CatSper genes family by selenium. Reproductive Biology and Endocrinology 7 126-131. (https://doi.org/10.1186/1477-7827-7-126)

Morakinyo AO, Iranloye BO \& Adegoke OA 2009 Antireproductive effect of calcium channel blockers on male rats. Reproductive Medicine and Biology 8 97-102. (https://doi.org/10.1007/s12522-009-0018-9)

Morakinyo AO, Iranloye BO, Daramola AO \& Adegoke OA 2011a Antifertility effect of calcium channel blockers on male rats: association with oxidative stress. Advances in Medical Sciences 56 95-105. (https:// doi.org/10.2478/v10039-011-0018-y)

Morakinyo AO, Iranloye BO \& Adegoke OA 2011b Calcium antagonists modulate oxidative stress and acrosomal reaction in rat spermatozoa. Archives of Medical Science 4 613-618. (https://doi.org/10.5114/ aoms.2011.24130) 
Navarro B, Kirichok Y, Chung JJ \& Clapham DE 2008 lon channels that control fertility in mammalian spermatozoa. International Journal of Developmental Biology 52 607-613. (https://doi.org/10.1387/ ijdb.072554bn)

Nikpoor P, Mowla SJ, Movahedin MS, Ziaee A-M \& Tiraihi T 2004 CatSper gene expression in postnatal development of mouse testis and in subfertile men with deficient sperm motility. Human Reproduction 19 124-128. (https://doi.org/10.1093/humrep/deh043)

Park EH, Kim DR, Kim HY, Park SK \& Chang MS 2014 Panax ginseng induces the expression of CatSper genes and sperm hyperactivation. Asian Journal of Andrology 16 845-851.

Phelps BM, Koppel DE, Primakoff P \& Myles DG 1990 Evidence that proteolysis of the surface is an initial step in the mechanism of formation of sperm cell surface domains. Journal of Cell Biology 111 1839-1847. (https://doi.org/10.1083/jcb.111.5.1839)

Qi H, Moran MM, Navarro B, Chong JA, Krapivinsky G, Krapivinsky L, Kirichok Y, Ramsey IS, Quill TA \& Clapham DE 2007 All four CatSper ion channel proteins are required for male fertility and sperm cell hyperactivated motility. PNAS 104 1219-1223. (https://doi.org/10.1073/ pnas.0610286104)

Quill TA, Sarah AS, Kristen LR, Lynda KD, Robert EH \& David LG 2003 Hyperactivated sperm motility driven by CatSper 2 is required for fertilization. PNAS 100 14869-14874. (https://doi.org/10.1073/ pnas.2136654100)

Robaire B \& Hamzeh M 2011 Androgen action in the epididymis. Journal of Andrology 32 592-599. (https://doi.org/10.2164/jandrol.111.014266)

Robaire B \& Henderson NA 2006 Actions of $5 \alpha$-reductase inhibitors on the epididymis. Molecular and Cellular Endocrinology 250 190-195. (https://doi.org/10.1016/j.mce.2005.12.044)

Ren D \& Xia J 2010 Calcium signaling through CatSper channels in mammalian fertilization. Physiology 25 165-175. (https://doi. org/10.1152/physiol.00049.2009)

Ren D, Navarro B, Perez G, Jackson A C, Hsu S, Shi Q, Tilly J L \& Clapham D E 2001 A sperm ion channel required for sperm motility and male fertility. Nature 413 603-609. (https://doi.org/10.1038/35098027)

Schmidt LJ, Regan KM, Anderson SK, Sun Z, Ballman KV \& Tindall DJ 2009 Effects of the 5 alpha-reductase inhibitor dutasteride on gene expression in prostate cancer xenografts. Prostate 69 1730-4173. (https://doi. org/10.1002/pros.21022)

Smith JF, Syritsyna O, Fellous M, Serres C, Mannowetz N, Kirichok Y \& Lishko PV 2013 Disruption of the principal, progesterone-activated sperm $\mathrm{Ca}^{2+}$ channel in a CatSper2-deficient infertile patient. PNAS 110 6823-6828. (https://doi.org/10.1073/pnas.1216588110)

Srivastav A 2000 Maturation-dependent glycoproteins containing both Nand O-linked oligosaccharides in epididymal sperm plasma membrane of rhesus monkey (Macaca mulatta). Journal of Reproduction and Fertility 119 241-252. (https://doi.org/10.1530/jrf.0.1190241)
Srivastav A, Chandra A, Singh M, Jamal F, Rastogi P, Rajendran SM, Bansode FW \& Lakshmi V 2010 Inhibition of hyaluronidase activity of human and rat spermatozoa in vitro and antispermatogenic activity in rats in vivo by Terminalia chebula, a flavonoid rich plant. Reproductive Toxicology $29214-224 . \quad$ (https://doi.org/10.1016/j. reprotox.2009.11.001)

Sun X-h, Zhu Y-y, Wang L, Liu H-I, Ling Y, Li Z-I and Sun L-b 2017 The CatSper channel and its roles in male fertility: a systematic review. Reproductive Biology and Endocrinology 15 65-76. (https://doi. org/10.1186/s12958-017-0281-2)

Tamburrino L, Marchiani S, Vicini E, Muciaccia BS, Cambi M, Pellegrini S, Forti G,Muratori M \& Baldi E 2015 Quantification of CatSper1 expression in human spermatozoa and relationship to functional parameters. Human Reproduction 30 1532-1544. (https://doi.org/10.1093/humrep/ $\operatorname{dev} 103)$

Viger RS \& Robaire B 1996 The mRNAs for the steroid $5 \alpha$-reductase isozymes, types 1 and 2, are differentially regulated in the rat epididymis. Journal of Andrology 17 27-34. (https://doi.org/10.1002/j.1939-4640.1996. tb00583.x)

Visconti PE, Krapf D, de la Vega-Beltran JL, Acevedo JJ \& Darszon A 2011 Ion channels, phosphorylation and mammalian sperm capacitation. Asian Journal of Andrology 13 395-405. (https://doi.org/10.1038/ aja.2010.69)

Wang YN, Wang B, Liang M, Han CY, Zhang B, Cai J, Sun W \& Xing GG 2013 Down-regulation of CatSper1 channel in epididymal spermatozoa contributes to the pathogenesis of asthenozoospermia, whereas upregulation of the channel by Sheng-Jing-San treatment improves the sperm motility of asthenozoospermia in rats. Fertility and Sterility $\mathbf{9 9}$ 579-587. (https://doi.org/10.1016/j.fertnstert.2012.10.030)

Wang HF, Changa $M$, Penga T-T, Yang $Y$, Lib N, Luob T, Cheng Y-M, Zhoua M-Z, Zeng X-H, Zheng L-P 2017 Exposure to cadmium impairs sperm functions by reducing CatSper in mice. Cellular Physiology and Biochemistry 42 44-54. (https://doi.org/10.1159/000477113)

Xie SW, Li GT, Qu LJ, Cao Y, Wang Q, Zhou JY, Zhong R-H, Guo XJ \& Zhu Y 2016 Identification of new epididymal luminal fluid proteins involved in sperm maturation in infertile rats treated by dutasteride using iTRAQ. Molecules 21 602-614. (https://doi.org/10.3390/molecules21050602)

Received 8 November 2017

First decision 11 December 2017

Revised manuscript received 19 January 2018

Accepted 5 February 2018 